\title{
Notch and Wnt signaling pathway in cancer: Crucial role and potential therapeutic targets (Review)
}

\author{
YU-FENG XIAO, XIN YONG, BO TANG, YONG QIN, \\ JIAN-WEI ZHANG, DAN ZHANG, RUI XIE and SHI-MING YANG
}

Department of Gastroenterology, Xinqiao Hospital, Third Military Medical University, Chongqing 400037, P.R. China

Received September 22, 2015; Accepted October 19, 2015

DOI: $10.3892 /$ ijo.2015.3280

\begin{abstract}
There is no radical cure for all cancer types. The most frequently used therapies are surgical treatment, radiotherapy and chemotherapy. However, recrudescence, radiation resistance and chemotherapy resistance are the most challenging issues in clinical practice. To address these issues, they should be further studied at the molecular level, and the signaling pathways involved represent a promising avenue for this research. In the present review, we mainly discuss the components and mechanisms of activation of the Notch and Wnt signaling pathways, and we summarize the recent research efforts on these two pathways in different cancers. We also evaluate the ideal drugs that could target these two signaling pathways for cancer therapy, summarize alterations in the Notch and Wnt signaling pathways in cancer, and discuss potential signaling inhibitors as effective drugs for cancer therapy.
\end{abstract}

\section{Contents}

1. Introduction

2. Notch signaling pathway

3. Wnt/ $\beta$-catenin signaling pathway

4. Conclusion

\section{Introduction}

It is well known that cancer is currently one of the leading causes of mortality in the world, and curing it still remains a great challenge to scientists and doctors. Many hypotheses and therapies have been suggested to explain and treat

Correspondence to: Professor Shi-Ming Yang, Department of Gastroenterology, Xinqiao Hospital, Third Military Medical University, Chongqing 400037, P.R. China

E-mail: shimingyang@yahoo.com

Key words: signaling pathway, Notch, Wnt, cancer, therapy cancer, and these have given hope to physicians and patients because many satisfactory results have been reported. However, there is currently no cancer cure and the mystery of cancer remains unsolved. The mechanism of tumor formation is largely unclear, and present hypotheses cannot explain all of the cases of tumor formation seen in medical practice. Even more noteworthy, therapy seems to be ineffective in some cases, especially in the terminal stages of cancer (1).

Theories regarding cancer biology can guide therapeutic strategies. The role of signal transduction pathways in cancer has been thoroughly investigated. Signaling pathways control the normal development of tissues and organs (2-5), and mutations in signaling molecules may lead to disease, even malignant cancer. A signaling pathway is a group of molecules that transduce signals intracellularly and intercellularly, affecting the fate of cells. The site of signal transduction is important in cancer development, and recent advances in signaling pathway research has provided the means to target therapy to specific sites (5). In addition, better understanding of signaling pathways may help solve the difficult problems of cancer therapy in daily medical practice, such as drug resistance (6). Shi et al (7) reported that inhibitor of p38 MAPK would increase drug sensitivity in colon cancer cell lines. A recent study also found that a decrease in SMAD4 promoter activity may lead to drug resistance in breast cancer cell lines (8). The data indicate that better understanding of signaling pathway function may provide insight into the mechanism of drug resistance and reveal potential target sites for improving drug sensitivity. Increasing evidence showed that mutations in signaling pathway components may also be an indicator of prognosis (9). A recent report showed that high Notch1 expression is associated with low survival rate in esophageal squamous cell cancer (10). Furthermore, Chu et al (11) reported that nuclear factorkappa B also influences the prognosis of oral squamous cell carcinoma. In addition, Wnt5a positivity was reported as a sign of short survival period in NSCLC (12). We can conclude from these data that signaling pathways may be unique prognosis markers for certain cancer types, and may also provide clues for further research on mechanism of cancer prognosis. Taken together, the view of signaling pathways could be a promising theory to explain cancer formation and may help guide therapy for cancer treatment in future. 


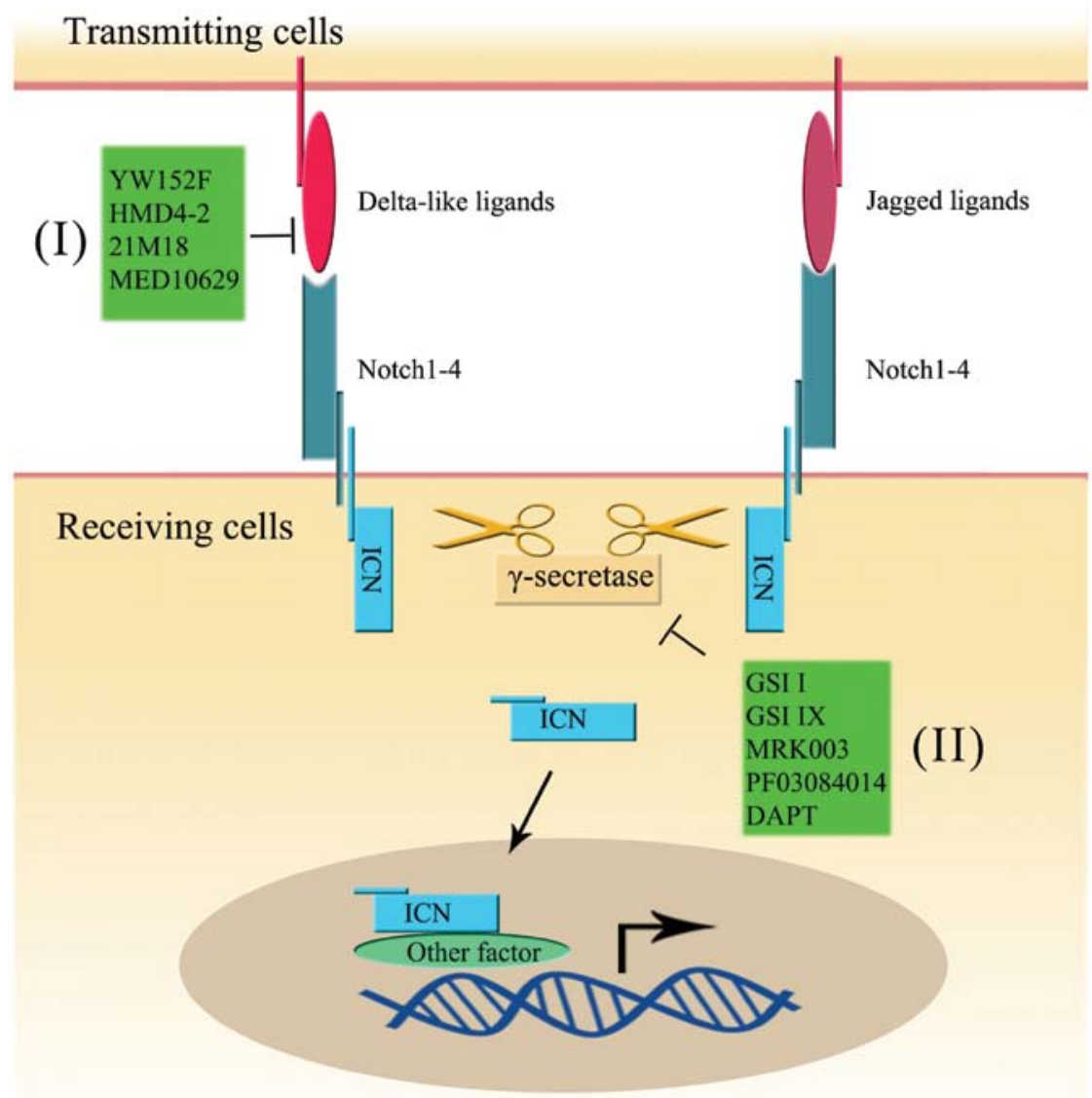

Figure 1. The Notch pathway. Delta-like ligands (DLL1, DLL3 and DLL4) and Jagged ligands (Jag1 and Jag2) interact with Notch receptors. The activation is controlled by TACE or $\gamma$-secretase. When intercellular activation occurs, the ICN are released by $\gamma$-secretase, then ICN translocates into the nucleus. (I/ II present the agents that target compounds of Notch signal pathway).

Many cancer-related signaling pathways have been reported, such as Notch, Wnt, NF-kB, Ras, JNK, ERK (3,13-16). These pathways have many aspects in common; for example, they all have a role in cellular proliferation, differentiation and survival. Notably, some signal pathways may play double roles in cancer, acting as both oncogene and suppressor, indicating that approach to therapy, based on signaling pathway sites, should be altered according the cancer type. Abnormal expression of signaling pathway components is observed in many cancers, which serves as a reminder that these components have a strong relationship with cancer. In the present review, we mainly focus on the Notch and Wnt signaling pathways to summarize their mechanism of activation, their role in tumorigenesis and their potential as targets for cancer therapy.

\section{Notch signaling pathway}

The Notch signaling pathway. The Notch signaling pathway is a conserved ligand-receptor signaling pathway in mammals that contains four Notch receptors and five ligands (17). The four receptors, which are named Notch 1, Notch 2, Notch 3 and Notch 4, share a similar structure. Each Notch receptor, Notch 1-4, has 36, 36, 34 and 29 epidermal growth factor (EGF)-like repeats, respectively $(18,19)$. The ligands can be divided into two major groups: the Delta-like ligands (DLL1,
DLL3 and DLL4) and Jagged ligands (Jag1 and Jag2) (17). The four Notch receptors and five ligands are transmembrane molecules, meaning that activation of the Notch signaling pathway controls cell fates by interaction of receptors and ligands on the surface of adjacent cells (20). Furthermore, the activation was shown to be regulated via proteolysis by metalloprotease, tumor necrosis factor- $\alpha$-converting enzyme (TACE) and $\gamma$-secretase $(21,22)$. When intercellular activation occurs, the extracellular and intracellular domains of the Notch receptor (ICN) are released by TACE and $\gamma$-secretase, respectively. Then, the extracellular domain binds to the ligand on the surface of an adjacent cell, and ICN translocates into the nucleus. ICN contains ankyrin repeats, a RAM domain, a trans-activation domain (TAD), a nuclear localization signal (NLS) and a PEST domain (23). Each domain is necessary for Notch signaling pathway activity. The ICN forms an active transcriptional complex and plays a direct role in regulating the gene expression $(23,24)$ (Fig. 1). From recent study data, the target genes of the Notch signaling pathway, to name a few, are the Hes family, Hey, NF- $\mathrm{kB}$, VEGF and c-myc. All of these Notch target genes were found to be associated with tumorigenesis (25-27).

It has also been shown that the Notch signaling pathway plays an important role in cell differentiation, proliferation and apoptosis (20). Increasing evidence showed that the Notch 
signaling pathway can affect the expression of inflammatory cytokines $(28,29)$, vasculogenesis $(30,31)$ and drug resistance (22). Thus, it is reasonable to speculate that disruptions in the Notch signaling pathway may lead to tumorigenesis, as many studies have reported. There is no doubt that a better understanding of the Notch signaling pathway may lead to new insight into cancer therapy and can bring hope to those who treat and suffer from Notch-related tumors.

The relationship between Notch and cancer. As previously discussed, the Notch signal pathway controls many cellular functions, such as differentiation, proliferation and apoptosis. When these functions are disrupted or altered, the outcome may be detrimental. Interestingly, the function of the Notch signaling pathway strongly depends on the cellular context (32). Notch can act both as an oncogene and suppressor gene (32). We mainly summarize the latest studies of the Notch signaling pathway in different tumors, from both oncogene and antioncogene points of view.

Notch signaling pathway in hematological malignancy. When discussing Notch-related cancer, human $\mathrm{T}$ lymphoblastic leukemias/lymphomas (T-ALL) should be given special attention as it was the first disease reported to be associated with Notch dysfunction in 1991 (33). T-ALL is a malignant tumor that occurs in young people. It has been shown that the intercellular domain of the Notch 1 receptor is the region that is most often mutated in human T-ALL $(34,35)$. A recent study also showed that mutations of the Notch 1 receptor were detected in $~ 50 \%$ of all T-ALL cases (36). From these data, we posit that the Notch 1 receptor has a strong relationship with T-ALL genesis, but how exactly the Notch 1 receptor contributes to T-ALL needs to be clarified.

Studies have demonstrated that the Notch 1 receptor played an important role in T-cell development and cell fate $(37,38)$, and therefore, Notch 1 receptor dysfunction negatively impacts T-cell function. There are three theories to explain how Notch 1 receptor mutation contributes to T-ALL. The most popular theory suggests that changes in the amino acid sequence (such as substitution, insertion and deletion) that encodes the heterodimerization domain lead to the abnormal sensitivity to the ligand (17,32). Another viewpoint suggests that a nonsense or frameshift mutation in the PEST domain, which was detected in $20-25 \%$ of T-ALLs, causes T-ALL $(17,32)$. The PEST domain controls the stability of intercellular Notch 1 (ICN1) and this mutation leads to an increase in the concentration of ICN1 $(17,36)$. The third theory implicates a mutation in the juxtamembrane expansion, which increases the activation of the Notch 1 receptor (39). Interestingly and unexpectedly, Notch 1 receptor mutations in T-ALL were associated with a good prognosis in recent studies (40-42). These results indicate that the Notch signaling pathway may be a novel target for the treatment of T-ALL and its mechanism of action in T-ALL should be further studied in detail.

In addition to T-ALL, the Notch signaling pathway is also dysregulated in other hematological malignancies. Chronic lymphocytic leukemia (CLL) is an incurable neoplasm with abnormal B cells. Increasing evidence from recent studies showed that the Notch signaling pathway plays a role in CLL, with the Notch 1 receptor mutant expressed in $\sim 10-20 \%$ patients $(17,32,43)$. Genetic studies reveal that the majority of mutations of the Notch 1 receptor are in the PEST domain $(44,45)$. In contrast to what is observed in T-ALL, Notch 1 receptor mutations indicate a poor prognosis in patients with CLL $(46,47)$, and higher frequency of mutation is also observed in chemorefractory CLL (43). In addition to the Notch 1 receptor, other Notch family members also play an important role in hematological malignancy. The Notch 2 receptor is involved in B cell development, which means that mutations in the Notch 2 receptor will likely lead to abnormal formation of $\mathrm{B}$ cells and result in further pathologic changes (48). Increasing evidence shows that a Notch 2 receptor mutation can be detected in tumors of B cell origin $(49,50)$.

Notch signaling pathway in solid tumors. In addition to its important role in the hematological malignancy, the Notch signaling pathway also has been shown to be involved in solid tumors, such as breast, lung, gastric and liver cancer. In these solid tumors, the dual role of Notch as an oncogene and suppressor gene is evident. We mainly focus below on the Notch signaling pathway in breast, lung and gastric cancer, aiming at summarizing the latest research advances on the Notch signaling pathway in these diseases.

Breast cancer. Research into the various roles of the Notch signaling pathway has been ongoing for some time. It is known that the Notch signaling pathway plays a crucial role in breast development (20). Evidence showed that the Notch 4 receptor and Notch 3 receptor control normal breast epithelial cells and luminal cells, respectively (51-53). Alteration of the Notch signaling pathway has the potential to cause breast cancer. Of special interest is that the four receptors of the Notch signaling pathway have different roles in breast cancer. The Notch 1 receptor, Notch 3 receptor and Notch 4 receptor have a negative signaling role in breast cancer (54-56). In recent studies, crosstalk of the Notch 1 receptor and other genes (such as Ras, c-myc and JAG1) was proven to contribute the formation of breast cancer $(35,54,57)$. Both the Notch 3 and Notch 4 receptors were found to have the potential to promote transformation $(55,56)$, and inhibition of Notch 3 receptor expression can reduce metastasis of breast cancer to the bone (58). Therefore, the Notch 3 receptor may be a drug target for the treatment of breast cancer. The Notch 1 receptor was associated with poor prognostic outcomes, while the Notch 2 receptor was associated with a good survival rate, as reported by Parr et al (59). They found that overexpression of the Notch 2 receptor can inhibit the tumor growth and promote tumor cell death, indicating that the Notch 2 receptor can be a promising target for further therapy.

Lung cancer. Lung cancer, which is the leading cause of cancer death in the world, can be divided into two types: small cell lung carcinoma (SCLC) and non-small cell lung carcinoma (NSCLC). Research of the Notch signaling pathway has been ongoing for a long time, but its role in lung cancer remains a subject of debate. As we previously mentioned, the role of the Notch signaling pathway in cancer depends on the cellular context, thus, the study of the Notch signaling pathway in lung cancer should be carried out in both SCLC and NSCLC. 
In a KrasG12D-driven endogenous NSCLC mouse model, Notch 1 deletion led to a reduction in tumor formation, while Notch 2 receptor deletion led to increased carcinogenesis (60). It was also found that Notch 2 receptor expression was weak in human NSCLC samples, indicating that Notch 2 may play the role of a tumor suppressor in NSCLC (60). Furthermore, in the study by Yang et al (61), it was found that Notch 1 activation may protect the A549 cell line against the antitumor effect of pterostilbene. Licciulli et al (62) also reported that the Notch 1 receptor is essential for tumor formation via suppression of p53. In addition, Notch 1 also seemed to be required for resistance to chemotherapy $(63,64)$ and radiotherapy in lung cancer (65). However, Wael et al (66) found that the Notch 1 receptor can significantly induce apoptosis in SCLC and the A549 adenocarcinoma cell line of NSCLC, while its tumor inhibitory function fails in SCC cells of NSCLC. A recent study demonstrated that the Notch 1 receptor can predict prognosis in lung adenocarcinomas: lower Notch 1 receptor expression in a lung adenocarcinoma cell line and patients with positive Notch 1 receptor expression have a longer survival time and a lower rate of recurrence (67). Taken together, before the role of the Notch 1 receptor in lung cancer can be confirmed, further studies are required. Compared with the Notch 1 receptor, the Notch 3 receptor has received less attention, but its role cannot be ignored. Zhou et al (68) detected Notch 3 receptor expression in different types of lung cancer, and they found that Notch 3 expression was high in lung squamous cell carcinoma and adenocarcinoma, but low in small cell carcinoma, compared with the corresponding non-tumor tissue. In addition, the Notch 3 receptor showed its potential ability of predicting the prognosis of patients with NSCLC (69). In this recent report, high levels of the Notch 3 receptor were detected in $\sim 51.1 \%$ of cases and were associated with a short survival rate.

Thus, taking all the evidence above into account, we conclude that the Notch signaling pathway is important in lung cancer genesis, progression and prognosis, and it is a promising target for therapy for lung cancer, though its role varies in different types of lung cancer.

Gastric cancer. Gastric cancer (GC) is one of the most common cancers in the world and it is also the leading cause of cancerrelated death (70), despite the fact that surgical resection and lymph node dissections are performed. Among the variety of factors that cause gastric cancer, the Notch signaling pathway seems to play an important role. The Notch 1 signaling pathway, in particular, draws great attention in the research of the Notch signaling pathway in GC. At present, Notch 1 seems to function as an oncoprotein in GC, as evidenced by a recent report that Notch 1 contributed to GC progression by inducing COX2 expression (71). Furthermore, Yao et al (72) reported that activation of the Notch 1 receptor can reduce $\mathrm{TNF} \alpha$-induced apoptosis in BGC-823 cells. Interestingly, though their structures are similar, Notch 1 and Notch 2 receptors have different roles in vivo (73). Sun et al (74) reported that expression of Notch 1 in different types of GC varies, indicating that Notch 1 may be a sign of gastric lesions with intestinal-like phenotypes, while the expression of Notch 2 showed a strong relationship with GC formation. However, the role of Notch 2 in GC remains indistinct. With evidence of an oncogenic role (75) and a suppressor role (76), Notch 2 should be further studied to confirm its function in GC.

In addition to the Notch receptors, ligands of the Notch signaling pathway have also received attention in GC. Recently, Piazzi et al (77) reported that the Delta-Like1 (DLL1) controlled the activation of the Notch 1 receptor in GC. Moreover, evidence also showed that DLL1 was the most important ligand for Notch 1 (78), indicating that DLL1 may be a potential target for Notch 1 receptor. Furthermore, another Notch ligand, Delta-Like4 (DLL4), was also reported to be involved in GC progression. Li et al (79) showed that activation of DLL4 may promote tumor proliferation, migration, invasion and tumorigenicity in SGC7901 via overexpression of MMP-2 proenzyme. Sun et al (80) also showed that DLL4 and Jagged1 siRNA gene therapy may greatly reduce the proliferation and invasion of the SGC7901 cell line.

\section{Wnt/ק-catenin signaling pathway}

The Wnt/ $\beta$-catenin signaling pathway. The Wnt signaling pathway has been a subject of research during the last several decades, and has been shown to function in cell proliferation, growth, cell fate and differentiation $(81,82)$. Mutation of Wnt signaling pathway components causes many diseases, including cancer (82). It is important to understand the Wnt signaling pathway also offers potential benefits for genetic therapy.

The components of the Wnt signaling pathway can be divided into Wnt ligands and Wnt receptors (83). There are 19 Wnt ligands, which all have a cysteine-rich domain, and may activate different types of Wnt signaling pathway by binding specific Wnt signaling receptors (84). In addition, some Wnt ligands are also involved in cancer formation and progression. Wnt1 encodes a number of glycoproteins and was reported as a sign of advanced metastasis for patients with tumors (85). Wnt3a was found to be overexpressed and associated with the level of MMP-9 in colorectal tumor tissue (86). Moreover, a recent report also showed that Wnt3a can promote the proliferation of MCF-7 cells by downregulating $\beta$-catenin acetylation (87).

Normally, the Wnt signaling pathway can be categorized as either the canonical Wnt pathway or non-canonical Wnt pathway (88). In the canonical Wnt pathway, $\beta$-catenin is the central molecule that controls the on/off 'switch' of the Wnt signaling pathway. The Wnt pathway is in the 'off' state when Wnt ligands do not bind to any receptors, and $\beta$-catenin is released from the cytomembrane. $\beta$-catenin is then captured by a protein complex, which is composed of adenomatous polyposis coli (APC), the scaffolding protein Axin, glycogen synthase kinase $3 \beta$ (GSK3 $\beta$ ) and casein kinase 1 (CK1) $(88,89)$. $\beta$-catenin is phosphorylated by CK1 and GSK $3 \beta$ and targeted for proteasomal degradation (89), leading to decreased $\beta$-catenin concentration, inhibition of nuclear translocation of $\beta$-catenin and thus, inhibition of target gene activation (88-90). When the switch is on, a different mechanism unfolds. Wnt ligands bind to the transmembrane Fz receptor and low-density lipoprotein receptor-related proteins (LRP5/6). Then, CK1 and GSK3 $\beta$ are attracted and function as a phosphorylase to LRP5/6. This leads to inacti- 
A

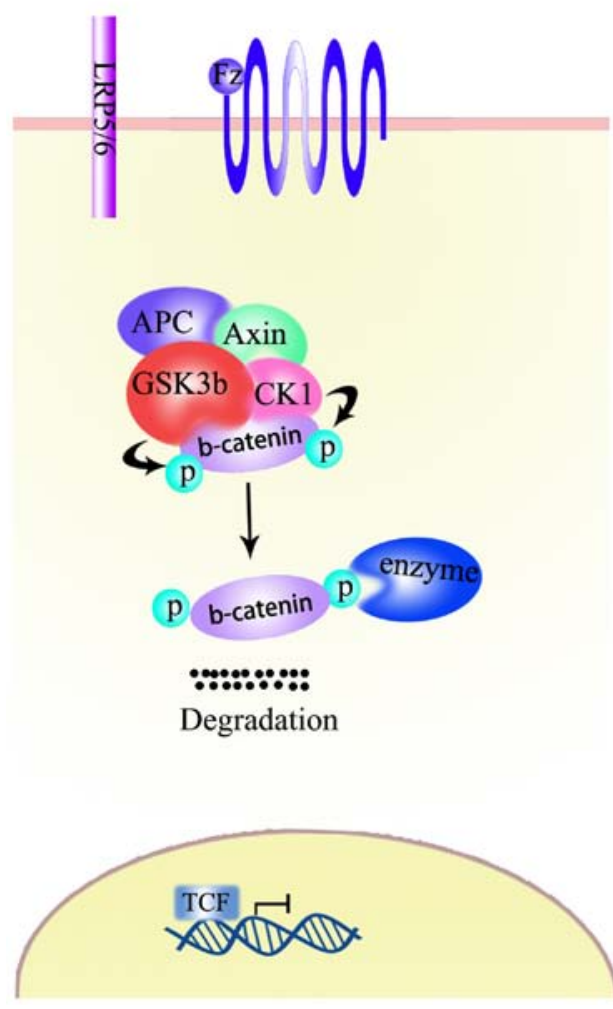

B

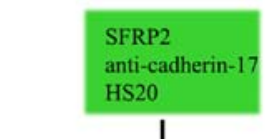

(I)

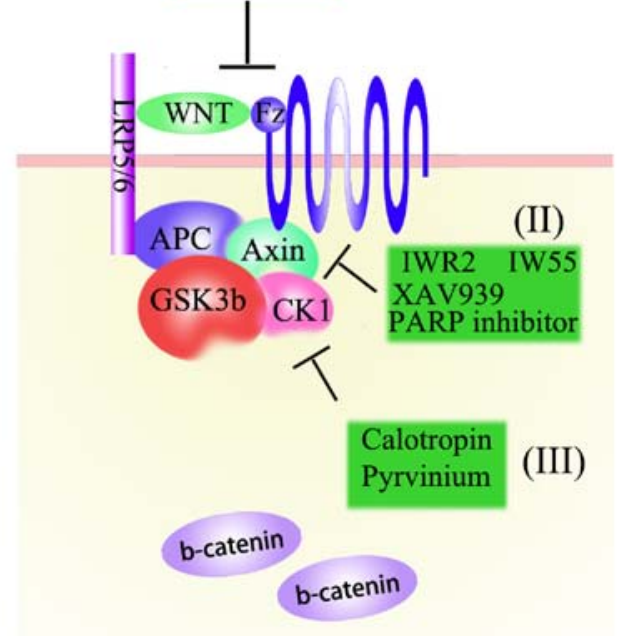

GDK-100017

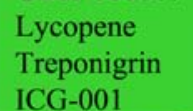

(IV)

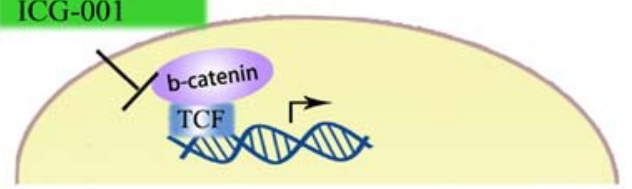

Figure 2. The canonical Wnt pathway. (A) Wnt ligands do not bind to any receptors, $\beta$-catenin is then captured by a protein complex (APC, GSK3 $\beta$, Axin and CK1). $\beta$-catenin is phosphorylated by CK1 and GSK3 $\beta$ and targeted for proteasomal degradation. (B) The Wnt ligands bind to the transmembrane Fz receptor and LRP5/6. Then, CK1 and GSK3 $\beta$ are attracted and function as a phosphorylase to LRP5/6. This leads to inactivation of the protein complex, and $\beta$-catenin cannot be caught by proteasome. (I/ II/ III/ IV present the agents that target the compounds of Wnt signal pathway)

vation of the protein complex, and $\beta$-catenin is able to escape degradation, making it possible for it to enter into the nucleus and promote the transcription of target genes $(88,91)$ (Fig. 2).

The non-canonical pathway, which is $\beta$-catenin independent, has two modes of activation: the $\mathrm{Wnt} / \mathrm{Ca}^{2+}$ pathway and the planar cell polarity (PCP) pathway $(92,93)$. In the $\mathrm{Wnt} / \mathrm{Ca}^{2+}$ pathway, Wnt ligands bind to the Frizzled (Fzd) transmembrane receptor and activate a series of proteins that increase the intracellular calcium level, which activates other signal pathways $(89,94)$. The PCP pathway leads to alterations in the cytoskeletal organization, which may influence cellular movement, metastasis and invasion $(88,93,95)$.

The relationship between Wht and cancer. It has been demonstrated that the Wnt signaling pathway is involved in deciding cellfate, and mutation of Wnt signaling pathway components also showed a strong association with different types of human cancer, such as lung, breast and ovarian cancer (83,96-98. Among these cancers, the Wnt signaling pathway is most involved in hepatocellular carcinoma (HCC) and colorectal cancer (CRC) $(99,100)$. In this section, we mainly discussed the recent research on the Wnt signaling pathway in HCC and CRC, summarizing the effect and potential drug targets of the Wnt signaling pathway in the two cancer types.
Wnt and hepatocellular carcinoma. HCC is the fifth most common cancer type worldwide, according a recent report (101). HCC has a poor prognosis and present treatments are surgical resection, transplantation and chemotherapy (101). The Wnt signaling pathway plays an important role in hepatocellular development, and increasing evidence shows that the Wnt signaling pathway is also involved in liver tumorigenesis (102). A recent report showed that the Wnt signaling pathway has been observed to be activated in at least $1 / 3$ of HCC (103). Hence, effective inhibition of the Wnt signaling pathway may be a potential treatment for HCC. Hou et al (104) reported in their recent research that mesenchymal stem cells (MSCs) were able to secrete Dkk-1 to inhibit proliferation and promote apoptosis of HepG2 cell lines by inhibiting expression of the Wnt signaling pathway. Their findings provided a new potential mechanism of how MSC injection could cure HCC. Zucchini-Pascal et al (105) also found that activation of the Wnt signaling pathway was essential for the epithelial to mesenchymal transition (EMT) in hepatocarcinoma. A study also showed that $\beta$-catenin could influence intercellular adhesion by affecting $\alpha$-catenin and E-cadherin (106). These reports indicated that the Wnt signaling pathway may also be involved in intrahepatic dissemination and distal metastasis of HCC. Furthermore, Singh et al (107) also found that deficiency of $\beta$-catenin could inhibit proliferation of liver adenomas in a 
mouse model. In addition to the effect on tumorigenesis and metastasis in liver, activation of the Wnt signaling pathway could also influence chemotherapy resistance in HCC by promoting the overexpression of aldehyde dehydrogenase isoforms (a marker ofchemotherapy resistance in cancer), as reported by Calderaro et al (108). It is well known that liver fibrosis is also involved in HCC, especially viral-related liver cancer (88), and increasing evidence also showed that the Wnt signal pathway may be involved. Cheng et al (109) found that the Wnt signaling pathway was upregulated in activated hepatic stellate cells. In addition, a recent report showed that liver fibrosis could be improved by inhibiting the Wnt signaling pathway (110).

From these data, we may preliminarily conclude that activation of the Wnt signaling pathway plays an important role in liver fibrosis, hepatocellular tumorigenesis and tumor development, and inhibition of the Wnt signaling pathway could strongly inhibit carcinogenesis.

Wnt and colorectal cancer. Colorectal cancer (CRC) is one of the most common cancers and one of the leading causes of cancer-related mortality in the world $(111,112)$. Gaining insight into the genetic changes of CRC is important for both treatment and diagnosis. Among the various genes involved in CRC, the Wnt signaling pathway has attracted much attention (113), as more than half of CRC cases have a $\beta$-catenin mutation (114). A recent report showed that the activation of different parts of Wnt signaling pathway may lead to development of one of two types of colorectal neoplasia: serrated or conventional adenoma/polyp (115). Accumulated research also showed that the application of Wnt signaling pathway inhibitors could greatly promote apoptosis and reduce proliferation of CRC cells $(116,117)$. Tumova et al (118) also reported that the use of monensin could inhibit expression of $\beta$-catenin in human colorectal carcinoma cells and decrease cell proliferation, indicating that $\mathrm{Wnt} / \beta$-catenin could be used as gene target for CRC and monensin is a potential drug for therapy. In addition, evidence from clinical practice also showed that CRC patients have a high rate of overexpression of Wnt signaling pathway proteins (119). Voorham et al (120) reported observation of methylated Wnt pathway antagonists from clinical specimens. It is possible that the Wnt signaling pathway could also be used as a potential diagnostic and prognostic biomarker in CRC patients $(119,121)$. Thus, both experimental and clinical data showed that the over activation of the Wnt signaling pathway may be a potential target for CRC. In addition to these studies of the oncogenic role of Wnt in CRC, Abdelmaksoud-Dammak et al (122) found that Wnt5a expression was lower in tumor compared with normal tissue, indicating that Wnt5a may play a role as an antioncogene in CRC. Interestingly, Bauer and colleagues found that the Wnt5a gene could result in proteins of different length, Wnt5a-long and Wnt5a-short. These two genes have inverse functions, with the Wnt5a-long functioning as a suppressor and Wnt5a-short as an oncogene (123).

From these data, we may conclude that $\mathrm{Wnt} / \beta$-catenin is an oncogenic pathway in CRC, though some Wnt ligands may act as suppressor, as some studies showed. Compounds that could inactivate $\mathrm{Wnt} / \beta$-catenin could be used as potential drugs for CRC.
Wnt and esophageal squamous cell carcinoma. Reports have shown that $\sim 95 \%$ esophageal cancer is esophageal squamous cell cancer (ESCC), with 15\% 5-year survival rate (124). At present, studies have found that Wnt signal pathway has played an indispensable role in the development of ESCC, indicating that the components of Wnt signal pathway could be the potential targets for treating ESCC.

Moyes et al (125) have reported that the expression of nuclear activated $\beta$-catenin was highly expressed in high grade of dysplasia when compared with that in Barrett's metaplasia. They also found that factitious expression of Wnt signal pathway in mouse oesophagus could cause tissue disorganization (125). Their results indicated that Wnt signal pathway plays an initiative effect in ESCC. In addition, a recent study showed that Wnt 10a, a component of Wnt signal pathway, promotes the invasive and self-renewing ability of ESCC (126), indicating that abnormal expression of Wnt signal pathway could promote the malignant activity of ESCC. From recent studies we may concluded that Wnt signal pathway is important in tumorigenesis and progression of ESCC, targeting components of Wnt signal pathway may make a contribution to treating ESCC both in the initial and the progression period.

Wnt inhibitory factor-1 (WIF1) is one of the most important Wnt inhibitors. A recent study has shown that WIF1 promoter is methylated in ESCC tissues, and re-expression of WIF1 could decrease the transcription activity of $\beta$-catenin/TCF and inhibit the cell proliferation and migration (127). Interestingly, Ge et al (128) found that the low expression of WIF1 in ESCC is due to the high expression of Hotair, which is a well-known long non-coding RNA. They reported that Hotair could directly promote histone $\mathrm{H} 3 \mathrm{~K} 27$ methylation in WIF1 promoter region and activated the Wnt signal pathway. In addition, Liu et al (129) reported that LKB1, a tumor suppressor, could inhibit the Wnt signal pathway through increasing GSK $3 \beta$ activity, causing low expression of $\beta$-catenin. Another tumor suppressor, SOX10, was also reported to inhibit the epithelial to mesenchymal transition (EMT) and stemness ability in ESCC cells, by competing with TCF4 to bind $\beta$-catenin (130).

From these studies, we may conclude that Wnt signal pathway plays an important role in ESCC. Abnormal expression of Wnt signal pathway may be the initial factor and the stimulative factor in ESCC. Moreover, studies have shown that targeting the components of Wnt signal pathway could inhibit the malignant activity of ESCC cell lines, indicating it is a potential treatment of ESCC.

Potential drug target for cancer therapy. As we have discussed above, both the Notch and Wnt signaling pathways have been proven to have a strong relationship with different types of tumors, playing dual roles of oncogene and suppressor. This means that the Notch and Wnt signaling pathway can be used as promising targets for therapy. In our opinion, the genetic therapy can be designed in three aspects: process or substance that actives genes, expression of the gene itself and mimic of the function of the genes.

Target Notch signaling pathway. The clinical approach to targeting the Notch signal pathway is divided into the use of 
Table I. Summary of the inhibitors in Notch signal pathway.

\begin{tabular}{|c|c|c|c|c|c|}
\hline Target & Drug & Model & Effect & Author & Refs. \\
\hline \multirow[t]{4}{*}{ DLL4 } & YW152F & HUVE cells & Deregulating angiogenesis & Ridgway et al & $(133)$ \\
\hline & HMD4-2 & Pancreatic cancer & Inhibit tumor growth and angiogenesis & Oishi et al & $(134)$ \\
\hline & $21 \mathrm{M} 18$ & Colorectal cancer & $\begin{array}{l}\text { Anticancer stem cell, anti-angiogenesis } \\
\text { and antitumor growth functions }\end{array}$ & Fischer et al & $(136)$ \\
\hline & MED10629 & HUVE cells & Inhibiting angiogenesis & Jenkins et al & $(137)$ \\
\hline Notch1 & $\begin{array}{l}602.101 \\
\text { (antibody) }\end{array}$ & Breast cancer & $\begin{array}{l}\text { Decrease cell proliferation and induce } \\
\text { apoptotic cell death }\end{array}$ & Sharma et al & $(141)$ \\
\hline \multirow[t]{4}{*}{$\gamma$-secretase } & GSI IX & Pancreatic cancer & Inhibit EMT & Palagani et al & $(144)$ \\
\hline & MRK003 & Breast cancer & Enhance docetaxel sensibility & Schott et al & $(145)$ \\
\hline & PF03084014 & $\begin{array}{l}\text { Chronic lymphocytic } \\
\text { leukemia }\end{array}$ & Anti-invasion & Lopez-Guerra et al & $(146)$ \\
\hline & DAPT & Gastric cancer & Inhibit EMT & Li et al & (149) \\
\hline
\end{tabular}

antibodies against the Notch receptor or ligand, and the inhibition of $\gamma$-secretase (5) (Fig. 1).

Antibodies targeting the Notch pathway. DLL4 plays an important role in Notch-related stem cell self-renewal, and its overexpression has been found in various tumors $(79,131,132)$. Thus, inhibition of DLL4 seems to be a promising treatment to cure cancer. The humanized phage antibody YW152F, could specifically bind to DLL4 receptor and was proven to be able to inhibit tumor growth by deregulating angiogenesis (133). The use of monoclonal antibodies against murine DLL4 (HMD4-2) in mice was also proven to be able to inhibit both tumor growth and angiogenesis (134). Monoclonal anti-DLL4 antibody, also known as $21 \mathrm{M} 18$, has drawn much attention. It has been reported that it could have anticancer stem cell, anti-angiogenesis and antitumor growth functions $(135,136)$. Recently, MED10629, an investigational human therapeutic antibody, was also reported in anti-interaction of DLL4 and Notch1, inhibiting angiogenesis in vivo (137). In addition, studies also showed that the combined use of DLL4 antibody and other therapies, such as radiation treatment and $\gamma$-secretase inhibitor, could improve the overall therapeutic effect $(138,139)$. Besides DLL4, other components of the Notch signaling pathway are targeted by antibodies. Aste-Amézaga et al (140) reported on an antibody that could target Notch1 and inhibit the expression of Notch target genes. Sharma et al (141) also showed the antibody against Notch1 could decrease cell proliferation and induce apoptotic cell death. From the data analyzed in the current study, we conclude that the use of an antibody against Notch seems to be a promising anticancer therapeutic strategy. However, antibodies against the Notch receptor should be used cautiously, for it has been reported that the chronic use of these antibodies could lead to vascular neoplasms (142).

Inhibition of $\gamma$-secretase. $\gamma$-secretase is a membrane protein that catalyzes intramembrane proteolysis (5). As previously mentioned, $\gamma$-secretase plays an important role in ICN release. Thus, the use of inhibitors of $\gamma$-secretase (GSIs) could be a promising therapy for Notch-related cancer. Rosati et al (143) reported that GSI I (Z-Leu-Leu-Nle-CHO) could induce apoptosis of primary chronic lymphatic leukemia (CLL) through three apoptosis factors. Palagani and colleagues found that the use of GSI IX could effectively inhibit epithelial mesenchymal transition (EMT) in human pancreatic ductal adenocarcinoma (PDAC) (144). Their findings showed a central role of Notch signal pathway in PDAC and the use of GSI IX has shown its potential in treating PDAC. Furthermore, Schott et al (145) reported that the use of GSI (MRK-003) could increase the efficacy of docetaxel in preclinical studies, indicating that the combination use of GSI and chemotherapy could be beneficial for the treatment of cancer. Similarly, another inhibitor, PF03084014, could also enhance the antitumor effect with the combination of fludarabine (146). Recently, Saito et al (147) reported that the use of $\gamma$-secretase inhibitors could inhibit the proliferation of glioma tumor-initiating cells. Groeneweg et al (148) reported that the effect of GSI in vitro is dose-dependent and could decrease tumor growth (Table I).

Target Wnt/ $\beta$-catenin signaling pathway. In the Wnt/ $\beta$-catenin signal pathway, $\beta$-catenin has been proven to play a central role in cancer. Thus, inhibitors of $\beta$-catenin could be used for cancer treatment (102). Dahmani et al (150) reported in their review that inhibitors of $\beta$-catenin could be divided into three types: those affecting the interaction between Wnt ligands and Fzd receptors, those that destroy complex stability and those affecting the activity of $\beta$-catenin in the nucleus.

In investigating the interaction between Wnt ligands and receptors, specific therapeutic antibodies have been widely used (150). Evidence has shown that antibodies that bind to Wnt ligands and receptors could inhibit the Wnt/ $\beta$-catenin signaling pathway (Table II). Fontenot et al (151) reported in their recent research that SFRP2 monoclonal antibody could induce the antitumor effect and inhibit the Wnt/ $\beta$-catenin signaling pathway in breast models. Wang and colleagues also found a dose-dependent effect of anti-cadherin-17 antibody in suppressing $\beta$-catenin in a HCC model (152). Similarly, Gao et al (153) reported that HS20, a human monoclonal 
Table II. Antibodies that target the Wnt signal pathway.

\begin{tabular}{lcccr}
\hline Antibody & Cell line & Author & Year & Refs. \\
\hline SFRP2 monoclonal antibody & 2H11 and MDA-MB-231 cells & Fontenot et al & 2013 & $(151)$ \\
Anti-cadherin-17 antibody & MHCC97L and MHCC97H & Wang et al & 2013 & $(152)$ \\
HS20 & Huh-1, Huh-4 & Gao et al & 2014 & $(153)$ \\
Anti-Wnt1 antibody & Huh-7 and SK-hep-1 & Wei et al & 2009 & $(170]$ \\
Anti-Lrp6 antibody & EKVX and M14 & Gong et al & 2010 & $(155)$ \\
Anti-Wnt2 antibody & LRK1A, REN, NCI-H2052, H28, H513, & Mazieres et al & 2005 & $(171)$ \\
& MS-1, NCI-H290, LP9 & & & \\
Anti-Fzd7 antibody & 'WT-stem cell' & Pode-Shakked et al & 2011 & $(172)$ \\
\hline
\end{tabular}

antibody against glypican-3, could disrupt the stability of Wnt3a and glypican-3 and inhibit the Wnt/ $\beta$-catenin signaling pathway in HCC cells. A recent study reported that a monoclonal antibody, which could target Fzd receptors and prevent their integration with Wnt ligands, has been widely used in treating cancer (89). Recent studies also showed that LRP5/6, closely related membrane receptors for the Wnt signaling pathway, can also be targeted by antibodies for further treatment in cancer $(154,155)$. In addition to antibodies, a number of molecules could also function as Wnt inhibitors. Wnt inhibitory proteins and secreted Fzd-related proteins were the most commonly studied molecules that bind to their targets, and as a result, they inhibit Wnt/ $\beta$-catenin activity (150). Fzd receptors were also reported to be potential targets for cancer treatment, as soluble Fzd-7 and Fzd-8 were reported to have antitumor effect $(150,156,157)$. IWP2 and Wnt-C59 could inhibit Wnt protein secretion and thus, prevent Wnt signal activation (101). Other molecules, such as flavonoids, monensin and resveratrol, were also shown to have potential antitumor ability via inhibition of the $\mathrm{Wnt} / \beta$-catenin signaling pathway $(118,158,159)$.

When targeting $\beta$-catenin to the destruction complex stability in cytoplasm, the situation seems to be complex. There are two approaches to targeting $\beta$-catenin in cytoplasm: the destruction complex stability and $\beta$-catenin itself. Axin, as one of the most important components in the destruction complex, has attracted a lot attention recently. Small peptides, such as IWR2 and IW55, were reported to prevent Axin from degradation and inhibit $\beta$-catenin activity (101). Other approaches to increase Axin stability could use a tankyrase inhibitor, such as XAV939, which could prevent the interaction of tankyrases and Axin (160). Parp poly-(ADP-ribose) polymerase (PARP) could promote the ribosylation of Axin, which would cause the degradation of Axin and increase $\beta$-catenin levels. The use of a PARP inhibitor could improve the level and stability of Axin, and thus reduce the activation of $\beta$-catenin (161). In addition to Axin, CK1 $\alpha$, another member of the destruction complex, is also a potential target for inhibiting $\beta$-catenin activity. In a recent study, Park et al (162) found that calotropin could inhibit the Wnt signaling pathway by increasing CK1 $\alpha$ protein levels. Their finding is the first to discover a small molecule that could increase CK1 $\alpha$ protein, indicating that calotropin could be used as a potential drug for cancer therapy. Additionally, the use of pyrvinium to treat familial adenomatous polyposis by inhibiting the Wnt signaling pathway via activation of CK1 $\alpha$ has also been reported (163).

Another approach to targeting the $\mathrm{Wnt} / \beta$-catenin signal pathway is nuclear, $\beta$-catenin and its co-activators are the targets. In the nucleus, the activation of Wnt $/ \beta$-catenin signaling is mediated by formation of a $\beta$-catenin/Lef-Tcf complex (150). Thus, a molecule that can disrupt this complex could be ideal for treating Wnt-related cancer. Wei et al (164)reported that they found three small molecules that could decrease Tcf $4 / \beta$ catenin binding capability and transcriptional activity in HCC cell lines, indicating that these three molecules could be used as anti-HCC drugs. Recently, a 2,3,6-trisubstituted quinoxaline derivative (GDK-100017) was also reported as an inhibitor of the $\beta$-catenin/Lef-Tcf complex, which also enhances radiosensitivity and reduces cell proliferation (165). In addition, lycopene was also reported to inhibit Wnt-Tcf signaling in breast cancer cells (166). Earlier, streponigrin was reported to inhibit the $\beta$-catenin/TCF complex binding to DNA, leading to a proliferation inhibitory effect (167). Furthermore, ICG-001 inhibited $\beta$-catenin activity in nucleus by disrupting $\beta$-catenin /CBP interaction (168) (Fig. 2).

\section{Conclusion}

In the present review, we mainly focused on the Notch signaling and Wnt signaling pathways, aiming to briefly describe the role of these two signaling pathway in different types of cancer and discussing inhibitors that may be potential anticancer therapies. Both the Notch and Wnt signaling pathways play an important role in maintaining normal cell fate, and these signaling pathways are also involved in a number of cancers. Better understanding of these signaling mechanisms could lead to better cancer therapies. Mutational and abnormal expression of Notch and Wnt signaling pathway components are observed in different types of cancer, as we have discussed in this review. Targeting these disrupted genes potentially reverse cancer damage, in as yet unknown manner. In recent studies, evidence has shown that the combination of signaling inhibitors and traditional therapy (such as radiotherapy and chemotherapy) can treat cancer more effectively compared with single therapy $(145,169)$. However, the biosafety of signaling pathway inhibitors should be closely monitored, as recent studies reported toxicity associated with chronic antibody application in clinical practice (142). Signaling pathways 
play an important role in tumorigenesis, tumor development and prognosis, and targeting signaling pathways has the potential to be effective for treating cancer.

\section{References}

1. Ramdass B, Duggal R, Minev B, Chowdhary A and Ramdass B, Duggal R, Minev B, Chowdhary A and Koka P: Functional role of solid tumor stem cells in disease etiology and susceptibility to therapeutic interventions. J Stem Cells 8: 189-231, 2013.

2. Chung E and Kondo M: Role of Ras/Raf/MEK/ERK signaling in physiological hematopoiesis and leukemia development. Immunol Res 49: 248-268, 2011.

3. Knight T and Irving JA: Ras/Raf/MEK/ERK pathway activation in childhood acute lymphoblastic leukemia and its therapeutic targeting. Front Oncol 4: 160, 2014.

4. Monga SP: Role and regulation of $\beta$-catenin signaling during physiological liver growth. Gene Expr 16: 51-62, 2014.

5. Andersson ER and Lendahl U: Therapeutic modulation of Notch signalling: are we there yet? Nat Rev Drug Discov 13: 357-378, 2014.

6. Pasillas MP, Shields S, Reilly R, Strnadel J, Behl C, Park R, Yates JR III, Klemke R, Gonias SL and Coppinger JA: Proteomic analysis reveals a role for Bcl2-associated athanogene 3 and major vault protein in resistance to apoptosis in senescent cells by regulating ERK1/2 activation. Mol Cell Proteomics 14: 1-14, 2015.

7. Shi X, Wu S, Yang Y, Tang L, Wang Y, Dong J, Lü B, Jiang G and Zhao W: AQP5 silencing suppresses p38 MAPK signaling and improves drug resistance in colon cancer cells. Tumour Biol 35: 7035-7045, 2014

8. Yu SL, Lee DC, Son JW, Park CG, Lee HY and Kang J: Histone deacetylase 4 mediates SMAD family member 4 deacetylation and induces 5-fluorouracil resistance in breast cancer cells. Oncol Rep 30: 1293-1300, 2013.

9. Jiang AG, Yu H and Huang JA: Expression and clinical significance of the phosphatidylinositol 3-kinase/protein kinase B signal transduction pathway in non-small cell lung carcinoma. Oncol Lett 8: 601-607, 2014.

10. Ogawa $\mathrm{R}$, Ishiguro $\mathrm{H}$, Kimura $\mathrm{M}$, Funahashi $\mathrm{H}$, Wakasugi $\mathrm{T}$, Ando T, Shiozaki M and Takeyama H: NOTCH1 expression predicts patient prognosis in esophageal squamous cell cancer. Eur Surg Ress 51: 101-107, 2013.

11. Chu W, Song X, Yang X, Ma L, Zhu J, He M, Wang Z and Wu Y: Neuropilin-1 promotes epithelial-to-mesenchymal transition by stimulating nuclear factor-kappa B and is associated with poor prognosis in human oral squamous cell carcinoma. PLoS One 9: e101931, 2014

12. Yao L, Sun B, Zhao X, Zhao X, Gu Q, Dong X, Zheng Y, Sun J, Cheng R, Qi H, et al: Overexpression of Wnt5a promotes angiogenesis in NSCLC. BioMed Res Int 2014: 832562, 2014.

13. Carvalho FL, Simons BW, Eberhart CG and Berman DM: Notch signaling in prostate cancer: A moving target. Prostate 74 933-945, 2014.

14. Jamieson $C$, Sharma $M$ and Henderson BR: Targeting the $\beta$-catenin nuclear transport pathway in cancer. Semin Cancer Biol 27: 20-29, 2014

15. Gasparini C, Celeghini C, Monasta L and Zauli G: NF-kappaB pathways in hematological malignancies. Cellular and molecular life sciences. Cell Mol Life Sci 71: 2083-2102, 2014.

16. Tournier C: The 2 Faces of JNK Signaling in Cancer. Genes Cancer 4: 397-400, 2013

17. Ntziachristos P, Lim JS, Sage J and Aifantis I: From fly wings to targeted cancer therapies: A centennial for notch signaling. Cancer Cell 25: 318-334, 2014.

18. Okajima T and Irvine KD: Regulation of notch signaling by o-linked fucose. Cell 111: 893-904, 2002.

19. Haines N and Irvine KD: Glycosylation regulates Notch signalling. Nat Rev Mol Cell Biol 4: 786-797, 2003.

20. Guo S, Liu M and Gonzalez-Perez RR: Role of Notch and its oncogenic signaling crosstalk in breast cancer. Biochim Biophys Acta 1815: 197-213, 2011

21. Lai EC: Notch signaling: Control of cell communication and cell fate. Development 131: 965-973, 2004.

22. Wang Z, Li Y, Ahmad A, Azmi AS, Banerjee S, Kong D and Sarkar FH: Targeting Notch signaling pathway to overcome drug resistance for cancer therapy. Biochim Biophys Acta 1806: $258-267,2010$
23. Kopan R and Ilagan MX: The canonical Notch signaling pathway: Unfolding the activation mechanism. Cell 137: 216-233, 2009.

24. Louvi A and Artavanis-Tsakonas S: Notch and disease: A growing field. Semin Cell Dev Biol 23: 473-480, 2012.

25. Rizzo P, Osipo C, Foreman K, Golde T, Osborne B and Miele L: Rational targeting of Notch signaling in cancer. Oncogene 27: 5124-5131, 2008

26. Wang Z, Banerjee S, Li Y, Rahman KM, Zhang Y and Sarkar FH: Down-regulation of notch-1 inhibits invasion by inactivation of nuclear factor-kappaB, vascular endothelial growth factor, and matrix metalloproteinase-9 in pancreatic cancer cells. Cancer Res 66: 2778-2784, 2006.

27. Wang Z, Zhang Y, Li Y, Banerjee S, Liao J and Sarkar FH: Down-regulation of Notch-1 contributes to cell growth inhibition and apoptosis in pancreatic cancer cells. Mol Cancer Ther 5: 483-493, 2006

28. Zavadil J, Cermak L, Soto-Nieves N and Böttinger EP: Integration of TGF-beta/Smad and Jagged1/Notch signalling in epithelial-to-mesenchymal transition. EMBO J 23: 1155-1165, 2004.

29. Sansone P, Storci G, Tavolari S, Guarnieri T, Giovannini C, Taffurelli M, Ceccarelli C, Santini D, Paterini P, Marcu KB, et al: IL-6 triggers malignant features in mammospheres from human ductal breast carcinoma and normal mammary gland. J Clin Invest 117: 3988-4002, 2007.

30. Patel NS, Li JL, Generali D, Poulsom R, Cranston DW and Harris AL: Up-regulation of delta-like 4 ligand in human tumor vasculature and the role of basal expression in endothelial cell function. Cancer Res 65: 8690-8697, 2005.

31. Lawson ND, Vogel AM and Weinstein BM: sonic hedgehog and vascular endothelial growth factor act upstream of the Notch pathway during arterial endothelial differentiation. Dev Cell 3: $127-136,2002$.

32. South AP, Cho RJ and Aster JC: The double-edged sword of Notch signaling in cancer. Semin Cell Dev Biol 23: 458-464, 2012.

33. Ellisen LW, Bird J, West DC, Soreng AL, Reynolds TC, Smith SD and Sklar J: TAN-1, the human homolog of the Drosophila notch gene, is broken by chromosomal translocations in T lymphoblastic neoplasms. Cell 66: 649-661, 1991.

34. Capobianco AJ, Zagouras P, Blaumueller CM, ArtavanisTsakonas S and Bishop JM: Neoplastic transformation by truncated alleles of human NOTCH1/TAN1 and NOTCH2. Mol Cell Biol 17: 6265-6273, 1997.

35. Girard L, Hanna Z, Beaulieu N, Hoemann CD, Simard C, Kozak CA and Jolicoeur P: Frequent provirus insertional mutagenesis of Notch1 in thymomas of MMTVD/myc transgenic mice suggests a collaboration of c-myc and Notch1 for oncogenesis. Genes Dev 10: 1930-1944, 1996.

36. Weng AP, Ferrando AA, Lee W, Morris JP IV, Silverman LB, Sanchez-Irizarry C, Blacklow SC, Look AT and Aster JC: Activating mutations of NOTCH1 in human T cell acute lymphoblastic leukemia. Science 306: 269-271, 2004.

37. Radtke F, Wilson A, Mancini SJ and MacDonald HR: Notch regulation of lymphocyte development and function. Nat Immunol 5: 247-253, 2004.

38. Hoyne GF: Notch signaling in the immune system. J Leukoc Biol 74: 971-981, 2003

39. Sulis ML, Williams O, Palomero T, Tosello V, Pallikuppam S, Real PJ, Barnes K, Zuurbier L, Meijerink JP and Ferrando AA: NOTCH1 extracellular juxtamembrane expansion mutations in T-ALL. Blood 112: 733-740, 2008.

40. Breit S, Stanulla M, Flohr T, Schrappe M, Ludwig WD, Tolle G, Happich M, Muckenthaler MU and Kulozik AE: Activating NOTCH1 mutations predict favorable early treatment response and long-term outcome in childhood precursor T-cell lymphoblastic leukemia. Blood 108: 1151-1157, 2006.

41. Park MJ, Taki T, Oda M, Watanabe T, Yumura-Yagi K, Kobayashi R, Suzuki N, Hara J, Horibe K and Hayashi Y: FBXW7 and NOTCH1 mutations in childhood T cell acute lymphoblastic leukaemia and $\mathrm{T}$ cell non-Hodgkin lymphoma. Br J Haematol 145: 198-206, 2009.

42. Clappier E, Collette S, Grardel N, Girard S, Suarez L, Brunie G, Kaltenbach S, Yakouben K, Mazingue F, Robert A, et al; EORTC-CLG: NOTCH1 and FBXW7 mutations have a favorable impact on early response to treatment, but not on outcome, in children with T-cell acute lymphoblastic leukemia (T-ALL) treated on EORTC trials 58881 and 58951. Leukemia 24: 2023-2031, 2010. 
43. Weissmann S, Roller A, Jeromin S, Hernández M, Abáigar M Hernández-Rivas JM, Grossmann V, Haferlach C, Kern W, Haferlach T, et al: Prognostic impact and landscape of NOTCH1 mutations in chronic lymphocytic leukemia (CLL): A study on 852 patients. Leukemia 27: 2393-2396, 2013

44. Di Ianni M, Baldoni S, Rosati E, Ciurnelli R, Cavalli L, Martelli MF, Marconi P, Screpanti I and Falzetti F: A new genetic lesion in B-CLL: A NOTCH1 PEST domain mutation. Br J Haematol 146: 689-691, 2009.

45. Sportoletti P, Baldoni S, Cavalli L, Del Papa B, Bonifacio E, Ciurnelli R, Bell AS, Di Tommaso A, Rosati E, Crescenzi B et al: NOTCH1 PEST domain mutation is an adverse prognostic factor in B-CLL. Br J Haematol 151: 404-406, 2010.

46. Wickremasinghe RG, Prentice AG and Steele AJ: p53 and Notch signaling in chronic lymphocytic leukemia: Clues to identifying novel therapeutic strategies. Leukemia 25: 1400-1407, 2011

47. Rossi D, Rasi S, Fabbri G, Spina V, Fangazio M, Forconi F, Marasca R, Laurenti L, Bruscaggin A, Cerri M, et al: Mutations of NOTCH1 are an independent predictor of survival in chronic lymphocytic leukemia. Blood 119: 521-529, 2012.

48. Kiel MJ, Velusamy T, Betz BL, Zhao L, Weigelin HG, Chiang MY, Huebner-Chan DR, Bailey NG, Yang DT, Bhagat G, et al: Whole-genome sequencing identifies recurrent somatic NOTCH2 mutations in splenic marginal zone lymphoma. J Exp Med 209: 1553-1565, 2012.

49. Lee SY, Kumano K, Nakazaki K, Sanada M, Matsumoto A, Yamamoto G, Nannya Y, Suzuki R, Ota S, Ota Y, et al: Gainof-function mutations and copy number increases of Notch2 in diffuse large B-cell lymphoma. Cancer Sci 100: 920-926, 2009.

50. Rossi D, Trifonov V, Fangazio M, Bruscaggin A, Rasi S, Spina V, Monti S, Vaisitti T, Arruga F, Famà R, et al: The coding genome of splenic marginal zone lymphoma: Activation of $\mathrm{NOTCH} 2$ and other pathways regulating marginal zone development. J Exp Med 209: 1537-1551, 2012

51. Uyttendaele H, Soriano JV, Montesano R and Kitajewski J: Notch4 and Wnt-1 proteins function to regulate branching morphogenesis of mammary epithelial cells in an opposing fashion. Dev Biol 196: 204-217, 1998.

52. Bellavia D, Checquolo S, Campese AF, Felli MP, Gulino A and Screpanti I: Notch3: From subtle structural differences to functional diversity. Oncogene 27: 5092-5098, 2008.

53. Melchor L and Smalley MJ: Highway to heaven: Mammary gland development and differentiation. Breast Cancer Res 10: 305, 2008

54. Weijzen S, Rizzo P, Braid M, Vaishnav R, Jonkheer SM,Zlobin A, Osborne BA, Gottipati S, Aster JC, Hahn WC, et al: Activation of Notch-1 signaling maintains the neoplastic phenotype in human Ras-transformed cells. Nat Med 8: 979-986, 2002.

55. Hu C, Diévart A, Lupien M, Calvo E, Tremblay G and Jolicoeur P Overexpression of activated murine Notch1 and Notch3 in transgenic mice blocks mammary gland development and induces mammary tumors. Am J Pathol 168: 973-990, 2006.

56. Imatani A and Callahan R: Identification of a novel NOTCH-4/ INT-3 RNA species encoding an activated gene product in certain human tumor cell lines. Oncogene 19: 223-231, 2000.

57. Reedijk M, Odorcic S, Chang L, Zhang H, Miller N, McCready DR, Lockwood G and Egan SE: High-level coexpression of JAG1 and NOTCH1 is observed in human breast cancer and is associated with poor overall survival. Cancer Res 65 : 8530-8537, 2005.

58. Zhang Z, Wang H, Ikeda S, Fahey F, Bielenberg D, Smits P and Hauschka PV: Notch3 in human breast cancer cell lines regulates osteoblast-cancer cell interactions and osteolytic bone metastasis. Am J Pathol 177: 1459-1469, 2010.

59. Parr C, Watkins G and Jiang WG: The possible correlation of Notch-1 and Notch-2 with clinical outcome and tumour clinicopathological parameters in human breast cancer. Int J Mol Med 14: 779-786, 2004.

60. Baumgart A, Mazur PK, Anton M, Rudelius M, Schwamborn K, Feuchtinger A, Behnke K, Walch A, Braren R, Peschel C, et al: Opposing role of Notch1 and Notch2 in a $\operatorname{Kras}(\mathrm{G} 12 \mathrm{D})$-driven murine non-small cell lung cancer model. Oncogene 34: 578-588, 2015.

61. Yang Y, Yan X, Duan W, Yan J, Yi W, Liang Z, Wang N, Li Y, Chen W, Yu S, et al: Pterostilbene exerts antitumor activity via the Notch1 signaling pathway in human lung adenocarcinoma cells. PLoS One 8: e62652, 2013

62. Licciulli S, Avila JL, Hanlon L, Troutman S, Cesaroni M, Kota S, Keith B, Simon MC, Puré E, Radtke F, et al: Notch1 is required for Kras-induced lung adenocarcinoma and controls tumor cell survival via p53. Cancer Res 73: 5974-5984, 2013.
63. Xie M, He CS, Wei SH and Zhang L: Notch-1 contributes to epidermal growth factor receptor tyrosine kinase inhibitor acquired resistance in non-small cell lung cancer in vitro and in vivo. Eur J Cancer 49: 3559-3572, 2013

64. Hassan KA, Wang L, Korkaya H, Chen G, Maillard I, Beer DG, Kalemkerian GP and Wicha M: Notch pathway activity identifies cells with cancer stem cell-like properties and correlates with worse survival in lung adenocarcinoma. Clin Cancer Res 19: 1972-1980, 2013

65. Theys J, Yahyanejad S, Habets R, Span P, Dubois L, Paesmans K, Kattenbeld B, Cleutjens J, Groot AJ, Schuurbiers OC, et al: High NOTCH activity induces radiation resistance in non small cell lung cancer. Radiother Oncol 108: 440-445, 2013.

66. Wael H, Yoshida R, Kudoh S, Hasegawa K, Niimori-Kita K and Ito T: Notch1 signaling controls cell proliferation, apoptosis and differentiation in lung carcinoma. Lung Cancer 85: 131-140, 2014.

67. Huang J, Song H, Liu B, Yu B, Wang R and Chen L: Expression of Notch-1 and its clinical significance in different histological subtypes of human lung adenocarcinoma. J Exp Clin Cancer Res 32: 84, 2013

68. Zhou M, Jin WY, Fan ZW and Han RC: Analysis of the expression of the Notch 3 receptor protein in adult lung cancer. Oncol Lett 5: 499-504, 2013

69. Ye YZ, Zhang ZH, Fan XY, Xu XL, Chen ML, Chang BW and Zhang YB: Notch3 overexpression associates with poor prognosis in human non-small-cell lung cancer. Med Oncol 30: $595,2013$.

70. Jemal A, Bray F, Center MM, Ferlay J, Ward E and Forman D: Global cancer statistics. CA Cancer J Clin 61: 69-90, 2011.

71. Yeh TS, Wu CW, Hsu KW, Liao WJ, Yang MC, Li AF, Wang AM, Kuo ML and Chi CW: The activated Notchl signal pathway is associated with gastric cancer progression through cyclooxygenase-2. Cancer Res 69: 5039-5048, 2009.

72. Yao J and Qian C: Over-activated Notch-1 protects gastric carcinoma BGC-823 cells from TNFalpha-induced apoptosis. Dig Liver Dis 41: 867-874, 2009.

73. Carson C, Murdoch B and Roskams AJ: Notch 2 and Notch $1 / 3$ segregate to neuronal and glial lineages of the developing olfactory epithelium. Dev Dyn 235: 1678-1688, 2006.

74. Sun Y, Gao X, Liu J, Kong QY, Wang XW, Chen XY, Wang Q, Cheng YF, Qu XX and Li H: Differential Notch1 and Notch2 expression and frequent activation of Notch signaling in gastric cancers. Arch Pathol Lab Med 135: 451-458, 2011.

75. Tseng YC, Tsai YH, Tseng MJ, Hsu KW, Yang MC, Huang KH, Li AF, Chi CW, Hsieh RH, Ku HH, et al: Notch2-induced COX-2 expression enhancing gastric cancer progression. Mol Carcinog 51: 939-951, 2012.

76. Guo LY, Li YM, Qiao L, Liu T, Du YY, Zhang JQ, He WT, Zhao YX and He DQ: Notch2 regulates matrix metallopeptidase 9 via PI3K/AKT signaling in human gastric carcinoma cell MKN-45. World J Gastroenterol 18: 7262-7270, 2012.

77. Piazzi G, Fini L, Selgrad M, Garcia M, Daoud Y, Wex T, Malfertheiner P, Gasbarrini A, Romano M, Meyer RL, et al: Epigenetic regulation of Delta-Like1 controls Notch1 activation in gastric cancer. Oncotarget 2: 1291-1301,2011.

78. Pellegrinet L, Rodilla V, Liu Z, Chen S, Koch U, Espinosa L, Kaestner KH, Kopan R, Lewis J and Radtke F: Dll1- and dll4-mediated notch signaling are required for homeostasis of intestinal stem cells. Gastroenterology 140: 1230-1240.e7, 2011.

79. Li GG, Li L, Li C, Ye LY, Li XW, Liu DR, Bao Q, Zheng YX, Xiang DP, Chen L, et al: Influence of up-regulation of Notch ligand DLL4 on biological behaviors of human gastric cancer cells. World J Gastroenterol 19: 4486-4494, 2013.

80. Sun HW, Wu C, Tan HY and Wang QS: Combination DLL4 with Jagged1-siRNA can enhance inhibition of the proliferation and invasiveness activity of human gastric carcinoma by Notch1/ VEGF pathway. Hepatogastroenterology 59: 924-929, 2012.

81. Logan CY and Nusse R: The Wnt signaling pathway in development and disease. Annu Rev Cell Dev Biol 20: 781-810, 2004.

82. Rosenbluh J, Wang $X$ and Hahn WC: Genomic insights into WNT/ $\beta$-catenin signaling. Trends Pharmacol Sci 35: 103-109, 2014.

83. MacDonald BT, Tamai K and $\mathrm{He} \mathrm{X}$ : Wnt/beta-catenin signaling: Components, mechanisms, and diseases. Dev Cell 17: 9-26, 2009.

84. Niehrs C: The complex world of WNT receptor signalling. Nat Rev Mol Cell Biol 13: 767-779, 2012.

85. Wang JM, Huang FC, Kuo MH, Wang ZF, Tseng TY, Chang LC, Yen SJ, Chang TC and Lin JJ: Inhibition of cancer cell migration and invasion through suppressing the Wnt1-mediating signal pathway by G-quadruplex structure stabilizers. J Biol Chem 289: $14612-14623,2014$ 
86. Lee MA, Park JH, Rhyu SY, Oh ST, Kang WK and Kim HN Wnt3a expression is associated with MMP-9 expression in primary tumor and metastatic site in recurrent or stage IV colorectal cancer. BMC Cancer 14: 125, 2014.

87. Wang SH, Li N, Wei Y, Li QR and Yu ZP: $\beta$-catenin deacetylation is essential for WNT-induced proliferation of breast cancer cells. Mol Med Rep 9: 973-978, 2014.

88. Miao CG, Yang YY, He X, Huang C, Huang Y, Zhang L, Lv XW, Jin Y and Li J: Wnt signaling in liver fibrosis: Progress, challenges and potential directions. Biochimie 95: 2326-2335, 2013.

89. Arend RC, Londoño-Joshi AI, Straughn JM Jr and Buchsbaum DJ: The Wnt/ $\beta$-catenin pathway in ovarian cancer: A review. Gynecol Oncol 131: 772-779, 2013.

90. Holland JD, Klaus A, Garratt AN and Birchmeier W: Wnt signaling in stem and cancer stem cells. Curr Opin Cell Biol 25: 254-264, 2013.

91. Barbolina MV, Burkhalter RJ and Stack MS: Diverse mechanisms for activation of Wnt signalling in the ovarian tumour microenvironment. Biochem J 437: 1-12, 2011

92. Andersen P, Uosaki H, Shenje LT and Kwon C: Non-canonical Notch signaling: Emerging role and mechanism. Trends Cell Biol 22: 257-265, 2012.

93. Clark CE, Nourse CC and Cooper HM: The tangled web of noncanonical Wnt signalling in neural migration. Neurosignals 20 : 202-220, 2012.

94. González-Sancho JM, Brennan KR, Castelo-Soccio LA and Brown AM: Wnt proteins induce dishevelled phosphorylation via an LRP5/6-independent mechanism, irrespective of their ability to stabilize beta-catenin. Mol Cell Biol 24: 4757-4768, 2004.

95. Beier F and Loeser RF: Biology and pathology of Rho GTPase, PI-3 kinase-Akt, and MAP kinase signaling pathways in chondrocytes. J Cell Biochem 110: 573-580, 2010.

96. Asad M, Wong MK, Tan TZ, Choolani M, Low J, Mori S, Virshup D, Thiery JP and Huang RY: FZD7 drives in vitro aggressiveness in Stem-A subtype of ovarian cancer via regulation of non-canonical Wnt/PCP pathway. Cell Death Dis 5: e1346, 2014

97. Bernemann C, Hülsewig C, Ruckert C, Schäfer S, Blümel L, Hempel G, Götte M, Greve B, Barth PJ, Kiesel L, et al: Influence of secreted frizzled receptor protein 1 (SFRP1) on neoadjuvant chemotherapy in triple negative breast cancer does not rely on WNT signaling. Mol Cancer 13: 174, 2014.

98. Xi Y and Chen Y: Wnt signaling pathway: Implications for therapy in lung cancer and bone metastasis. Cancer Lett 353 8-16, 2014.

99. Nejak-Bowen KN and Monga SP: Beta-catenin signaling, liver regeneration and hepatocellular cancer: Sorting the good from the bad. Semin Cancer Biol 21: 44-58, 2011.

100. Colussi D, Brandi G, Bazzoli F and Ricciardiello L: Molecular pathways involved in colorectal cancer: Implications for disease behavior and prevention. Int J Mol Sci 14: 16365-16385, 2013.

101. Pez F, Lopez A, Kim M, Wands JR, Caron de Fromentel C and Merle P: Wnt signaling and hepatocarcinogenesis: Molecular targets for the development of innovative anticancer drugs. J Hepatol 59: 1107-1117, 2013.

102. Armengol C, Cairo S, Fabre M and Buendia MA: Wnt signaling and hepatocarcinogenesis: The hepatoblastoma model. Int J Biochem Cell Biol 43: 265-270, 2011.

103. Gedaly R, Galuppo R, Daily MF, Shah M, Maynard E, Chen C, Zhang X, Esser KA, Cohen DA, Evers BM, et al: Targeting the $\mathrm{Wnt} / \beta$-catenin signaling pathway in liver cancer stem cells and hepatocellular carcinoma cell lines with FH535. PLoS One 9: e99272, 2014.

104. Hou L, Wang X, Zhou Y, Ma H, Wang Z, He J, Hu H, Guan W and Ma Y: Inhibitory effect and mechanism of mesenchymal stem cells on liver cancer cells. Tumour Biol 35: 1239-1250, 2014.

105. Zucchini-Pascal N, Peyre L and Rahmani R: Crosstalk between beta-catenin and snail in the induction of epithelial to mesenchymal transition in hepatocarcinoma: Role of the ERK1/2 pathway. Int J Mol Sci 14: 20768-20792, 2013

106. Bustos VH, Ferrarese A, Venerando A, Marin O, Allende JE and Pinna LA: The first armadillo repeat is involved in the recognition and regulation of beta-catenin phosphorylation by protein kinase CK1. Proc Natl Acad Sci USA 103: 19725-19730, 2006.

107. Singh Y, Port J, Schwarz M and Braeuning A: Genetic ablation of $\beta$-catenin inhibits the proliferative phenotype of mouse liver adenomas. Br J Cancer 111: 132-138, 2014.
108. Calderaro J, Nault JC, Bioulac-Sage P, Laurent A, Blanc JF, Decaens T and Zucman-Rossi J: ALDH3A1 is overexpressed in a subset of hepatocellular carcinoma characterised by activation of the Wnt/ss-catenin pathway. Virchows Arch 464: 53-60, 2014.

109. Cheng JH, She H, Han YP, Wang J, Xiong S, Asahina K and Tsukamoto H: Wnt antagonism inhibits hepatic stellate cell activation and liver fibrosis. Am J Physiol Gastrointest Liver Physiol 294: G39-G49, 2008

110. Li W, Zhu C, Li Y, Wu Q and Gao R: Mest attenuates CCl4induced liver fibrosis in rats by inhibiting the Wnt/ $\beta$-catenin signaling pathway. Gut Liver 8: 282-291, 2014

111. Tenesa A and Dunlop MG: New insights into the aetiology of colorectal cancer from genome-wide association studies. Nat Rev Genet 10: 353-358, 2009.

112. Pandurangan AK: Potential targets for prevention of colorectal cancer: A focus on PI3K/Akt/mTOR and Wnt pathways. Asian Pac J Cancer Prev 14: 2201-2205, 2013.

113. Curtin JC: Novel drug discovery opportunities for colorectal cancer. Expert Opin Drug Discov 8: 1153-1164, 2013.

114. Sparks AB, Morin PJ, Vogelstein B and Kinzler KW: Mutational analysis of the APC/beta-catenin/Tcf pathway in colorectal cancer. Cancer Res 58: 1130-1134, 1998.

115. Murakami T, Mitomi H, Saito T, Takahashi M, Sakamoto N, Fukui N, Yao T and Watanabe S: Distinct WNT/beta-catenin signaling activation in the serrated neoplasia pathway and the adenoma-carcinoma sequence of the colorectum. Mod Pathol 28: 146-158, 2015

116. Raghu D and Karunagaran D: Plumbagin downregulates Wnt signaling independent of p53 in human colorectal cancer cells. J Nat Prod 77: 1130-1134, 2014.

117. Tai WP, Hu PJ, Wu J and Lin XC: The inhibition of $\mathrm{Wnt} / \beta$ catenin signaling pathway in human colon cancer cells by sulindac. Tumori 100: 97-101, 2014

118. Tumova L, Pombinho AR, Vojtechova M, Stancikova J, Gradl D, Krausova M, Sloncova E, Horazna M, Kriz V, Machonova O, et al: Monensin inhibits canonical Wnt signaling in human colorectal cancer cells and suppresses tumor growth in multiple intestinal neoplasia mice. Mol Cancer Ther 13: 812-822, 2014.

119. Bruun J, Kolberg M, Nesland JM, Svindland A, Nesbakken A and Lothe RA: Prognostic Significance of $\beta$-catenin, E-cadherin, and SOX9 in colorectal cancer: Results from a large populationrepresentative series. Front Oncol 4: 118, 2014.

120. Voorham QJ, Janssen J, Tijssen M, Snellenberg S, Mongera S, van Grieken NC, Grabsch H, Kliment M, Rembacken BJ, Mulder CJ, et al: Promoter methylation of Wnt-antagonists in polypoid and nonpolypoid colorectal adenomas. BMC Cancer 13: 603, 2013.

121. Serafino A, Moroni N, Zonfrillo M, Andreola F, Mercuri L, Nicotera G, Nunziata J, Ricci R, Antinori A, Rasi G, et al: WNT-pathway components as predictive markers useful for diagnosis, prevention and therapy in inflammatory bowel disease and sporadic colorectal cancer. Oncotarget 5: 978-992, 2014.

122. Abdelmaksoud-Dammak R, Miladi-Abdennadher I, SaadallahKallel A, Khabir A, Sellami-Boudawara T, Frikha M, Daoud J and Mokdad-Gargouri R: Downregulation of WIF-1 and Wnt5a in patients with colorectal carcinoma: clinical significance. Tumour Biol 35: 7975-7982, 2014.

123. Bauer M, Bénard J, Gaasterland T, Willert K and Cappellen D: WNT5A encodes two isoforms with distinct functions in cancers. PLoS One 8: e80526, 2013.

124. Chai J, Modak C, Ouyang Y, Wu SY and Jamal MM: CCN1 Induces $\beta$-catenin translocation in esophageal squamous cell carcinoma through integrin $\alpha 11$. ISRN Gastroenterol 2012: 207235, 2012.

125. Moyes LH, McEwan H, Radulescu S, Pawlikowski J, Lamm CG, Nixon C, Sansom OJ, Going JJ, Fullarton GM and Adams PD: Activation of Wnt signalling promotes development of dysplasia in Barrett's oesophagus. J Pathol 228: 99-112, 2012.

126. Long A, Giroux V, Whelan KA, Hamilton KE, Tétreault MP, Tanaka K, Lee JS, Klein-Szanto AJ, Nakagawa H and Rustgi AK: WNT10A promotes an invasive and self-renewing phenotype in esophageal squamous cell carcinoma. Carcinogenesis 36: 598-606, 2015.

127. Yang SH, Li SL, Dong ZM and Kan QC: Epigenetic inactivation of Wnt inhibitory factor-1 in human esophageal squamous cell carcinoma. Oncol Res 20: 123-130, 2012. 
128. Ge XS, Ma HJ, Zheng XH, Ruan HL, Liao XY, Xue WQ, Chen YB, Zhang Y and Jia WH: HOTAIR, a prognostic factor in esophageal squamous cell carcinoma, inhibits WIF-1 expression and activates Wnt pathway. Cancer Sci 104: 1675-1682, 2013.

129. Liu K, Luo Y, Tian H, Yu KZ, He JX and Shen WY: The tumor suppressor LKB1 antagonizes WNT signaling pathway through modulating GSK3beta activity in cell growth of esophageal carcinoma. Tumour Biol 35: 995-1002, 2014

130. Tong X, Li L, Li X, Heng L, Zhong L, Su X, Rong R, Hu S, Liu W, Jia B, et al: SOX10, a novel HMG-box-containing tumor suppressor, inhibits growth and metastasis of digestive cancers by suppressing the $\mathrm{Wnt} / \beta$-catenin pathway. Oncotarget 5 : 10571-10583, 2014

131. Kuramoto T, Goto H, Mitsuhashi A, Tabata S, Ogawa H, Uehara H, Saijo A, Kakiuchi S, Maekawa Y, Yasutomo K, et al: Dll4-Fc, an inhibitor of Dll4-notch signaling, suppresses liver metastasis of small cell lung cancer cells through the downregulation of the NF- $\kappa \mathrm{B}$ activity. Mol Cancer Ther 11: 2578-2587, 2012.

132. Stewart KS, Zhou Z, Zweidler-McKay P and Kleinerman ES Delta-like ligand 4-Notch signaling regulates bone marrowderived pericyte/vascular smooth muscle cell formation. Blood 117: 719-726, 2011

133. Ridgway J, Zhang G, Wu Y, Stawicki S, Liang WC, Chanthery Y, Kowalski J, Watts RJ, Callahan C, Kasman I, et al: Inhibition of Dll4 signalling inhibits tumour growth by deregulating angiogenesis. Nature 444: 1083-1087, 2006.

134. Oishi H, Sunamura M, Egawa S, Motoi F, Unno M, Furukawa T, Habib NA and Yagita H: Blockade of delta-like ligand 4 signaling inhibits both growth and angiogenesis of pancreatic cancer. Pancreas 39: 897-903, 2010.

135. Gurney A and Hoey T: Anti-DLL4, a cancer therapeutic with multiple mechanisms of action. Vasc Cell 3: 18, 2011.

136. Fischer M, Yen WC, Kapoun AM, Wang M, O'Young G, Lewicki J, Gurney A and Hoey T: Anti-DLL4 inhibits growth and reduces tumor-initiating cell frequency in colorectal tumors with oncogenic KRAS mutations. Cancer Res 71: 1520-1525, 2011.

137. Jenkins DW, Ross S, Veldman-Jones M, Foltz IN, Clavette BC, Manchulenko K, Eberlein C, Kendrew J, Petteruti P, Cho S, et al: MEDI0639: A novel therapeutic antibody targeting Dll4 modulates endothelial cell function and angiogenesis in vivo. Mol Cancer Ther 11: 1650-1660, 2012.

138. Liu SK, Bham SA, Fokas E, Beech J, Im J, Cho S, Harris AL and Muschel RJ: Delta-like ligand 4-notch blockade and tumor radiation response. J Natl Cancer Inst 103: 1778-1798, 2011.

139. El Kaffas A, Nofiele J, Giles A, Cho S, Liu SK and Czarnota GJ: Dll4-notch signalling blockade synergizes combined ultrasound-stimulated microbubble and radiation therapy in human colon cancer xenografts. PLoS One 9: e93888, 2014.

140. Aste-Amézaga M, Zhang N, Lineberger JE, Arnold BA, Toner TJ, Gu M, Huang L, Vitelli S, Vo KT, Haytko P, et al: Characterization of Notch 1 antibodies that inhibit signaling of both normal and mutated Notch1 receptors. PLoS One 5: e9094, 2010.

141. Sharma A, Paranjape AN, Rangarajan A and Dighe RR: A monoclonal antibody against human Notch1 ligand-binding domain depletes subpopulation of putative breast cancer stem-like cells. Mol Cancer Ther 11: 77-86, 2012.

142. Yan M, Callahan CA, Beyer JC, Allamneni KP, Zhang G, Ridgway JB, Niessen K and Plowman GD: Chronic DLL4 blockade induces vascular neoplasms. Nature 463: E6-E7, 2010.

143. Rosati E, Sabatini R, De Falco F, Del Papa B, Falzetti F, Di Ianni M, Cavalli L, Fettucciari K, Bartoli A, Screpanti I, et al: gamma-Secretase inhibitor I induces apoptosis in chronic lymphocytic leukemia cells by proteasome inhibition, endoplasmic reticulum stress increase and notch down-regulation. Int J Cancer 132: 1940-1953, 2013.

144. Palagani V, El Khatib M, Kossatz U, Bozko P, Müller MR, Manns MP, Krech T, Malek NP and Plentz RR: Epithelial mesenchymal transition and pancreatic tumor initiating CD44 ${ }^{+}$ $\mathrm{EpCAM}^{+}$cells are inhibited by $\gamma$-secretase inhibitor IX. PLoS One 7: e46514, 2012.

145. Schott AF, Landis MD, Dontu G, Griffith KA, Layman RM, Krop I, Paskett LA, Wong H, Dobrolecki LE, Lewis MT, et al: Preclinical and clinical studies of gamma secretase inhibitors with docetaxel on human breast tumors. Clin Cancer Res 19: 1512-1524, 2013.
146. López-Guerra M, Xargay-Torrent S, Rosich L, Montraveta A, Roldán J, Matas-Céspedes A, Villamor N, Aymerich M, López-Otín C, Pérez-Galán P, et al: The $\gamma$-secretase inhibitor PF-03084014 combined with fludarabine antagonizes migration, invasion and angiogenesis in NOTCH1-mutated CLL cells. Leukemia 29: 96-106, 2015.

147. Saito N, Fu J, Zheng S, Yao J, Wang S, Liu DD, Yuan Y, Sulman EP, Lang FF, Colman H, et al: A high Notch pathway activation predicts response to $\gamma$ secretase inhibitors in proneural subtype of glioma tumor-initiating cells. Stem Cells 32: 301-312, 2014.

148. Groeneweg JW, Hall TR, Zhang L, Kim M, Byron VF, Tambouret R, Sathayanrayanan S, Foster R, Rueda BR and Growdon WB: Inhibition of gamma-secretase activity impedes uterine serous carcinoma growth in a human xenograft model. Gynecol Oncol 133: 607-615, 2014.

149. Li LC, Peng Y, Liu YM, Wang LL and Wu XL: Gastric cancer cell growth and epithelial-mesenchymal transition are inhibited by $\gamma$-secretase inhibitor DAPT. Oncol Lett 7: 2160-2164, 2014.

150. Dahmani R, Just PA and Perret C: The Wnt $/ \beta$-catenin pathway as a therapeutic target in human hepatocellular carcinoma. Clin Res Hepatol Gastroenterol 35: 709-713, 2011.

151. Fontenot E, Rossi E, Mumper R, Snyder S, SiamakpourReihani S, Ma P, Hilliard E, Bone B, Ketelsen D, Santos C, et al: A novel monoclonal antibody to secreted frizzled-related protein 2 inhibits tumor growth. Mol Cancer Ther 12: 685-695, 2013.

152. Wang Y, Shek FH, Wong KF, Liu LX, Zhang XQ, Yuan Y, Khin E, Hu MY, Wang JH, Poon RT, et al: Anti-cadherin-17 antibody modulates beta-catenin signaling and tumorigenicity of hepatocellular carcinoma. PLoS One 8: e72386, 2013.

153. Gao W, Kim H, Feng M, Phung Y, Xavier CP, Rubin JS and Ho M: Inactivation of Wnt signaling by a human antibody that recognizes the heparan sulfate chains of glypican-3 for liver cancer therapy. Hepatology 60: 576-587, 2014.

154. Ettenberg SA, Charlat O, Daley MP, Liu S, Vincent KJ, Stuart DD, Schuller AG, Yuan J, Ospina B, Green J, et al: Inhibition of tumorigenesis driven by different Wnt proteins requires blockade of distinct ligand-binding regions by LRP6 antibodies. Proc Natl Acad Sci USA 107: 15473-15478, 2010.

155. Gong Y, Bourhis E, Chiu C, Stawicki S, DeAlmeida VI, Liu BY, Phamluong K, Cao TC, Carano RA, Ernst JA, et al: Wnt isoform-specific interactions with coreceptor specify inhibition or potentiation of signaling by LRP6 antibodies. PLoS One 5: e12682, 2010.

156. Lavergne E, Hendaoui I, Coulouarn C, Ribault C, Leseur J, Eliat PA, Mebarki S, Corlu A, Clément B and Musso O: Blocking Wnt signaling by SFRP-like molecules inhibits in vivo cell proliferation and tumor growth in cells carrying active $\beta$-catenin. Oncogene 30: 423-433, 2011.

157. Wei W, Chua MS, Grepper S and So SK: Soluble Frizzled-7 receptor inhibits Wnt signaling and sensitizes hepatocellular carcinoma cells towards doxorubicin. Mol Cancer 10: 16, 2011.

158. Amado NG, Predes D, Moreno MM, Carvalho IO, Mendes FA and Abreu JG: Flavonoids and Wnt/ $\beta$-catenin signaling: Potential role in colorectal cancer therapies. Int J Mol Sci 15: 12094-12106, 2014.

159. Ji Q, Liu X, Fu X, Zhang L, Sui H, Zhou L, Sun J, Cai J, Qin J, Ren J, et al: Resveratrol inhibits invasion and metastasis of colorectal cancer cells via MALAT1 mediated Wnt $/ \beta$-catenin signal pathway. PLoS One 8: e78700, 2013.

160. Huang SM, Mishina YM, Liu S, Cheung A, Stegmeier F, Michaud GA, Charlat O, Wiellette E, Zhang Y, Wiessner S, et al: Tankyrase inhibition stabilizes axin and antagonizes Wnt signalling. Nature 461: 614-620, 2009.

161. Waaler J, Machon O, Tumova L, Dinh H, Korinek V, Wilson SR, Paulsen JE, Pedersen NM, Eide TJ, Machonova O, et al: A novel tankyrase inhibitor decreases canonical Wnt signaling in colon carcinoma cells and reduces tumor growth in conditional APC mutant mice. Cancer Res 72: 2822-2832, 2012.

162. Park HY, Toume K, Arai MA, Sadhu SK, Ahmed F and Ishibashi M: Calotropin: A cardenolide from calotropis gigantea that inhibits Wnt signaling by increasing casein kinase $1 \alpha$ in colon cancer cells. ChemBioChem 15: 872-878, 2014.

163. Li B, Flaveny CA, Giambelli C, Fei DL, Han L, Hang BI, Bai F, Pei XH, Nose V, Burlingame O, et al: Repurposing the FDA-approved pinworm drug pyrvinium as a novel chemotherapeutic agent for intestinal polyposis. PLoS One 9: e101969, 2014. 
164. Wei W, Chua MS, Grepper S and So S: Small molecule antagonists of Tcf4/beta-catenin complex inhibit the growth of HCC cells in vitro and in vivo. Int J Cancer 126: 2426-2436, 2010.

165. Lee SB, Gong YD, Park YI and Dong MS: 2,3,6-Trisubstituted quinoxaline derivative, a small molecule inhibitor of the Wnt/ beta-catenin signaling pathway, suppresses cell proliferation and enhances radiosensitivity in A549/Wnt2 cells. Biochem Biophys Res Commun 431: 746-752, 2013.

166. Preet R, Mohapatra P, Das D, Satapathy SR, Choudhuri T, Wyatt MD and Kundu CN: Lycopene synergistically enhances quinacrine action to inhibit Wnt-TCF signaling in breast cancer cells through APC. Carcinogenesis 34: 277-286, 2013.

167. Park S and Chun S: Streptonigrin inhibits $\beta$-catenin/Tcf signaling and shows cytotoxicity in $\beta$-catenin-activated cells Biochim Biophys Acta 1810: 1340-1345, 2011.

168. Emami KH, Nguyen C, Ma H, Kim DH, Jeong KW, Eguchi M, Moon RT, Teo JL, Kim HY, Moon SH, et al: A small molecule inhibitor of beta-catenin/CREB-binding protein transcription [corrected]. Proc Natl Acad Sci USA 101: 12682-12687, 2004.
169. Yu SD, Liu FY and Wang QR: Notch inhibitor: A promising carcinoma radiosensitizer. Asian Pac J Cancer Prev 13 5345-5351, 2012.

170. Wei W, Chua MS, Grepper S and So SK: Blockade of Wnt-1 signaling leads to anti-tumor effects in hepatocellular carcinoma cells. Mol Cancer 8: 76, 2009

171. Mazieres J, You L, He B, Xu Z, Twogood S, Lee AY, Reguart N, Batra S, Mikami I and Jablons DM: Wnt2 as a new therapeutic target in malignant pleural mesothelioma. Int J Cancer 117: 326-332, 2005.

172. Pode-Shakked N, Harari-Steinberg O, Haberman-Ziv Y, Rom-Gross E, Bahar S, Omer D, Metsuyanim S, Buzhor E, Jacob-Hirsch J, Goldstein RS, et al: Resistance or sensitivity of Wilms' tumor to anti-FZD7 antibody highlights the Wnt pathway as a possible therapeutic target. Oncogene 30: 1664-1680, 2011. 